\title{
Association between teat-end hyperkeratosis and mastitis in dairy cows: A systematic review
}

\author{
J. C. F. Pantoja, ${ }^{*}$ (1) L. B. N. Correia, R. S. Rossi, and G. S. Latosinski \\ Department of Veterinary Hygiene and Public Health, School of Veterinary Medicine and Animal Science, Sao Paulo State University (UNESP), \\ Botucatu, SP, Brazil, 18618-681
}

\begin{abstract}
A systematic review was conducted to elucidate the role of teat-end hyperkeratosis (THK) as a risk factor for clinical mastitis (CM) or subclinical mastitis (SCM). Scientific papers on the subject were identified by means of a database search. All types of peer-reviewed analytical studies, observational or experimental and published in English, could be included in the review, regardless of publication year. Of 152 identified records, 18 articles were selected, of which 8 were prospective cohort studies, 9 were cross-sectional, and 1 was a hybrid case-control study. Internal validity of studies was assessed using a score system ranging from 0 to 6 , based on design, risk of bias, and statistical methods. The most frequent study limitation was improper use of statistical methods to avoid confounding of associations between THK and CM or SCM. The 3 studies that used $\mathrm{CM}$ as outcome (all with high validity scores) showed positive associations with THK (especially severe), although the magnitude and statistical significance of the estimates differed among them. Most studies that used SCM as the primary outcome (based on microbiological examination of milk) reported that only severe THK was associated with SCM. Two studies with high validity scores reported moderate to strong associations between severe THK and incidence or prevalence of Staphylococcus aureus intramammary infection. Two studies with high validity scores reported that only severe THK was associated with the risk of somatic cell count $(\mathrm{SCC}) \geq 200,000$ cells $/ \mathrm{mL}$ and increased mean SCC, respectively. Although 4 cross-sectional studies reported positive associations between THK and SCC, these associations were possibly spurious because confounding factors, such as parity, were not considered in the analyses. Results of the reviewed studies suggest that severe THK is a risk factor for both CM and SCM, as defined by microbiological examination of milk, SCC
\end{abstract}

Received April 16, 2019.

Accepted October 8, 2019.

*Corresponding author: jose.pantoja@unesp.br thresholds, or mean SCC. The effect of severe THK on both contagious (especially Staphylococcus aureus) and environmental CM or SCM emphasizes the importance of teat health for mastitis control. Four studies demonstrated that quarters with mild THK had lower prevalence of intramammary infection or lower mean SCC than quarters with no THK, suggesting that development of mild THK, as a physiological response to milking, can have a protective effect. Dairy consultants should focus on monitoring and minimizing occurrence of severe THK to prevent CM and SCM.

Key words: mastitis, dairy cow, teat-end hyperkeratosis, teat-end callosity, somatic cell count

\section{INTRODUCTION}

Teat-end hyperkeratosis (THK) is one of the most prevalent pathologies of dairy cows, being characterized by hyperplasia of the teat orifice's keratin layer in response to chronic stimuli (Blowey and Weaver, 2011). In a scale ranging from 1 (no THK) to 4 (severe THK; Mein et al., 2001), the prevalence of Holstein cow teats scored as 3 ranged between $21.5 \%$ (415/1,931; de Pinho Manzi et al., 2012; Brazil) and 46.5\% (939/2,019; Zoche-Golob et al., 2015; Germany) and scored as 4 ranged between 12.5\% (51/408; Paduch et al., 2012; Germany) and 18.8\% (39/207; Pantoja et al., 2016; Brazil).

Cows factors such as teat shape (Neijenhuis et al., 2001), teat position (front or rear; Neijenhuis et al., 2001; Mitev et al., 2012), stage of lactation (Neijenhuis et al., 2001), parity (Sandrucci et al., 2014; Pantoja et al., 2016), peak milk production (Neijenhuis et al., 2001), and machine-on time (Neijenhuis et al., 2000) have all been associated with THK. At the herd level, milking management factors and equipment settings, such as teat-end vacuum, pulsation system, duration of the pulsation cycle's D phase, liner characteristics (compression, tension, and material), and overmilking, have been associated with THK (Neijenhuis et al., 2000; Mein et al., 2001; Zucali et al., 2008; Sterrett et al., 2013). 
The teat orifice, by means of anatomical and physiological mechanisms, is the primary defense barrier of the mammary gland against mastitis pathogens (Breen et al., 2006). These mechanisms are composed of stratified squamous cells filled with keratin, which act as a physical barrier, fatty acids with bacteriostatic action, and muscular tissue that maintains the teat canal closed between milkings (Breen et al., 2006).

It has been hypothesized that tissue changes around the teat canal resulting from THK facilitate harboring and entry of bacteria into the mammary gland and, consequently, occurrence of mastitis (Mein, 2012). Paduch et al. (2012) conducted a cross-sectional study including 204 pairs of teats (99 pairs of front teats and 105 pairs of rear teats) from 2 herds in Germany and reported that THK was associated with the number of colony-forming units of Streptococcus uberis and Escherichia coli isolated from the teat canal. No association was observed between THK and retrieval of Staphylococcus aureus. Nonetheless, scientific evidence demonstrating the complete causal pathway including THK as a risk factor for impairment of the teat canal, increased teat-end contamination, and, consequently, mastitis, is still lacking.

Although teat-end scoring is a common practice among dairy consultants and THK has been considered a strong risk factor for clinical mastitis (CM) and subclinical mastitis (SCM), results of scientific studies are controversial. Due to the small number of peer-reviewed studies and methodology limitations, the objective of this systematic review was to elucidate the role of THK as a risk factor for CM or SCM in dairy cows. Specific research questions were as follows: (1) Is THK associated with CM? and (2) Is THK associated with SCM, as defined by microbiological examination of milk, SCC, or both?

\section{MATERIALS AND METHODS}

\section{Inclusion and Exclusion Criteria}

The review protocol was performed according to the Preferred Reporting Items for Systematic Reviews and Meta-Analyses: The PRISMA Statement (Moher et al., 2009).
Eligible studies had to be original research papers, peer-reviewed, and published in English (any year). Studies had to be analytical (experimental or observational) and report associations between THK and CM or SCM in dairy cows of any breed, regardless of geographic location. Descriptive studies such as case series and case reports were not eligible for inclusion. Eligible mastitis outcomes were CM (based on visual examination of milk and the mammary gland), SCM (based on microbiological examination of milk or SCC thresholds), or SCC (as a continuous variable). Teatend hyperkeratosis had to be assessed in categorical, ordinal scales, to allow quantification of scores.

\section{Search Strategy and Sources of Information}

Searching was independently performed by 2 authors (L. B. N. Correia and R. S. Rossi) in October 2017. A search was performed combining key words and Boolean operators, under advisement of a librarian. Medical subject headings and thesaurus terms were used to describe the population of interest (dairy cows), the risk factor (THK), and the outcomes (CM or SCM). The detailed search strategy for each consulted database is described in Table 1. The same search was repeated in December 2018 (restricted by this year) to identify any study published during preparation of the review.

\section{Study Selection and Data Extraction}

Records identified by the initial search were analyzed independently by all authors. After removal of duplicates (Figure 1), 36 records were excluded by mutual agreement because they did not meet the more obvious inclusion criteria (off topic, theses, book chapters, and conference papers). An additional 29 studies were excluded after abstract analysis because of language, not reporting measures of association, being review articles, or lack of eligible outcomes. Eleven articles were then selected for full-text analysis and met the inclusion criteria. Seven eligible articles were further identified by screening of reference lists, resulting in 18 included studies.

Data extraction was performed by all authors. A standardized form was used to collect the follow-

Table 1. Search terms and databases used to retrieve research papers about the association between teat-end hyperkeratosis and occurrence of clinical or subclinical mastitis

\begin{tabular}{ll}
\hline Databases & Terms \\
\hline PubMed & (teat AND (hyperkeratosis OR callosity)) AND (cattle OR cow*) AND (mastitis OR (somatic cell count)) \\
Web of Science & (teat AND (hyperkeratosis OR callosity)) AND (cattle OR cow*) AND (mastitis OR "somatic cell count") \\
Scopus & (teat AND (hyperkeratosis OR callosity)) AND (cattle OR cow*) AND (mastitis OR "somatic cell count") \\
CABI Direct & (teat AND (hyperkeratosis OR callosity)) AND (cattle OR cow*) AND (mastitis OR "somatic cell count") \\
\hline
\end{tabular}


ing information from selected articles: authors, year of publication, study period, study design, country (state), study sample (number of observations and cow characteristics), unit of analysis, method of THK scoring, definition of mastitis outcomes, and main results (Tables 2, 3, and 4).

\section{Assessment of Validity and Reporting}

As all included studies were observational, the Strengthening the Reporting of Observational Studies in Epidemiology (STROBE; Sargeant et al., 2016) was used to assess completeness of reporting and availability of necessary information to evaluate internal and external validity. Eighteen items are common for cohort, case-control, and cross-sectional studies and 4 items are specific for each of these study designs (Sargeant et al., 2016). The percentage of STROBE attended items was then calculated for each reviewed study (Table 5).

Internal validity was assessed using a score system adapted from Dahl et al. (2017), based on study design, risk of bias, and statistical methods. Scores given to each of the 3 criteria ranged from 0 (least strength of evidence) to 2 (greatest strength of evidence) and were added to assign a final score ranging from 0 to 6 .

Cohort, case-control, and cross-sectional studies were given scores 2, 1 , and 0 , respectively, based on strength of evidence. Risk of introducing outcome (CM or SCM) and exposure (THK) biases was scored according to the Newcastle-Ottawa Scale for assessing the quality of nonrandomized studies in meta-analyses (Wells et al., 2014). Because 2 was the maximum score for risk of bias, the percentage of Newcastle-Ottawa Scale-attended items was calculated to assign the score for each reviewed study. For example, studies that attended $50 \%$ of Newcastle-Ottawa Scale items were scored as 1.

The statistical methods score was defined as follows: $2=$ used proper multivariable modeling to account for covariates and confounders, and accounted for repeated measures or lack of independence among quarters within cow, or cows within herd; $1=$ did not use multivariable modeling but accounted for confounders in some extent (e.g., use of stratified analysis), or used multivariable modeling without considering repeated measurements or lack of independence among quarters within cow, or cows within herd; and $0=$ did not use multivariable

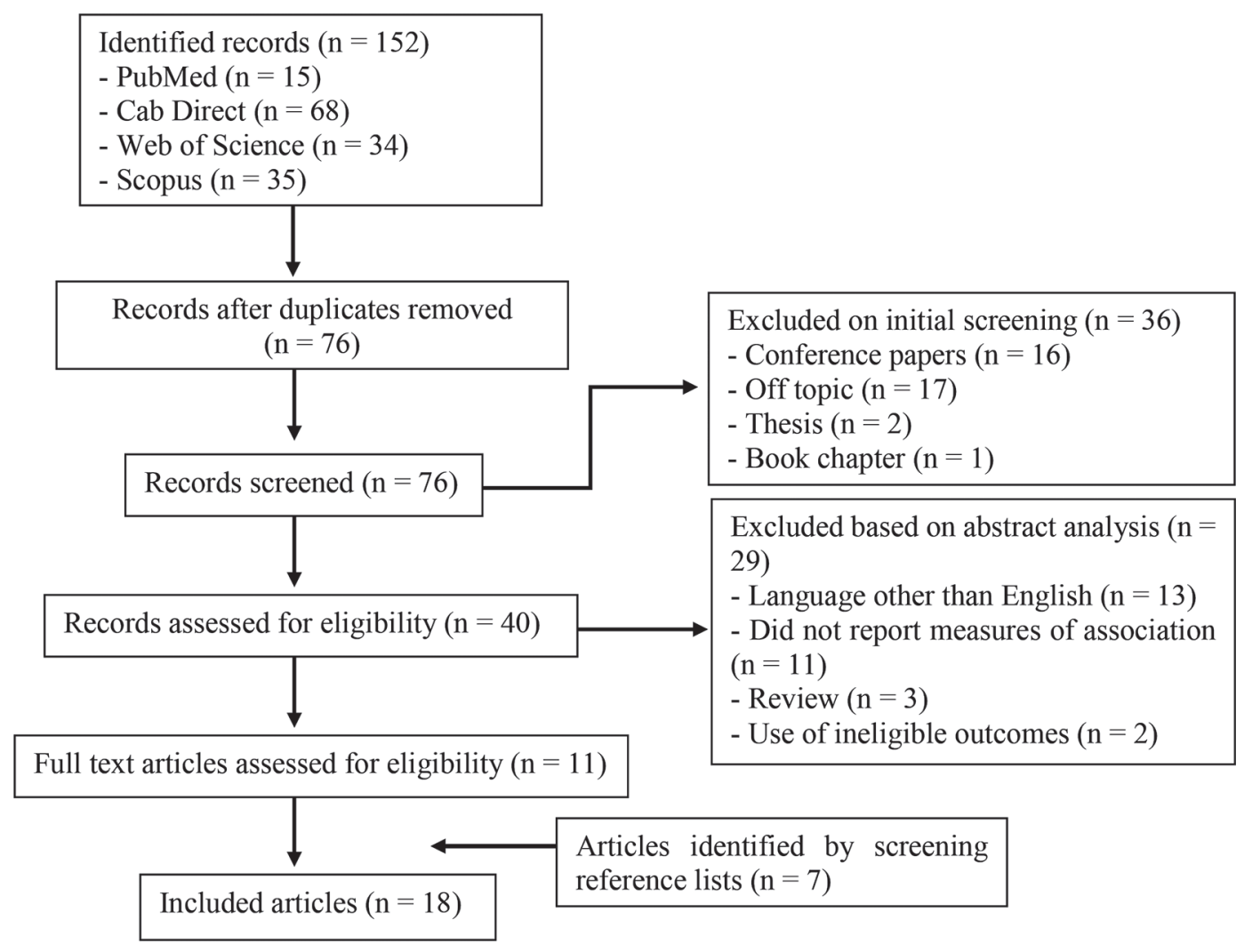

Figure 1. Process of identification and selection of relevant scientific literature about the association between teat-end hyperkeratosis and occurrence of mastitis. 
Pantoja et al.: TEAT-END HYPERKERATOSIS AND MASTITIS

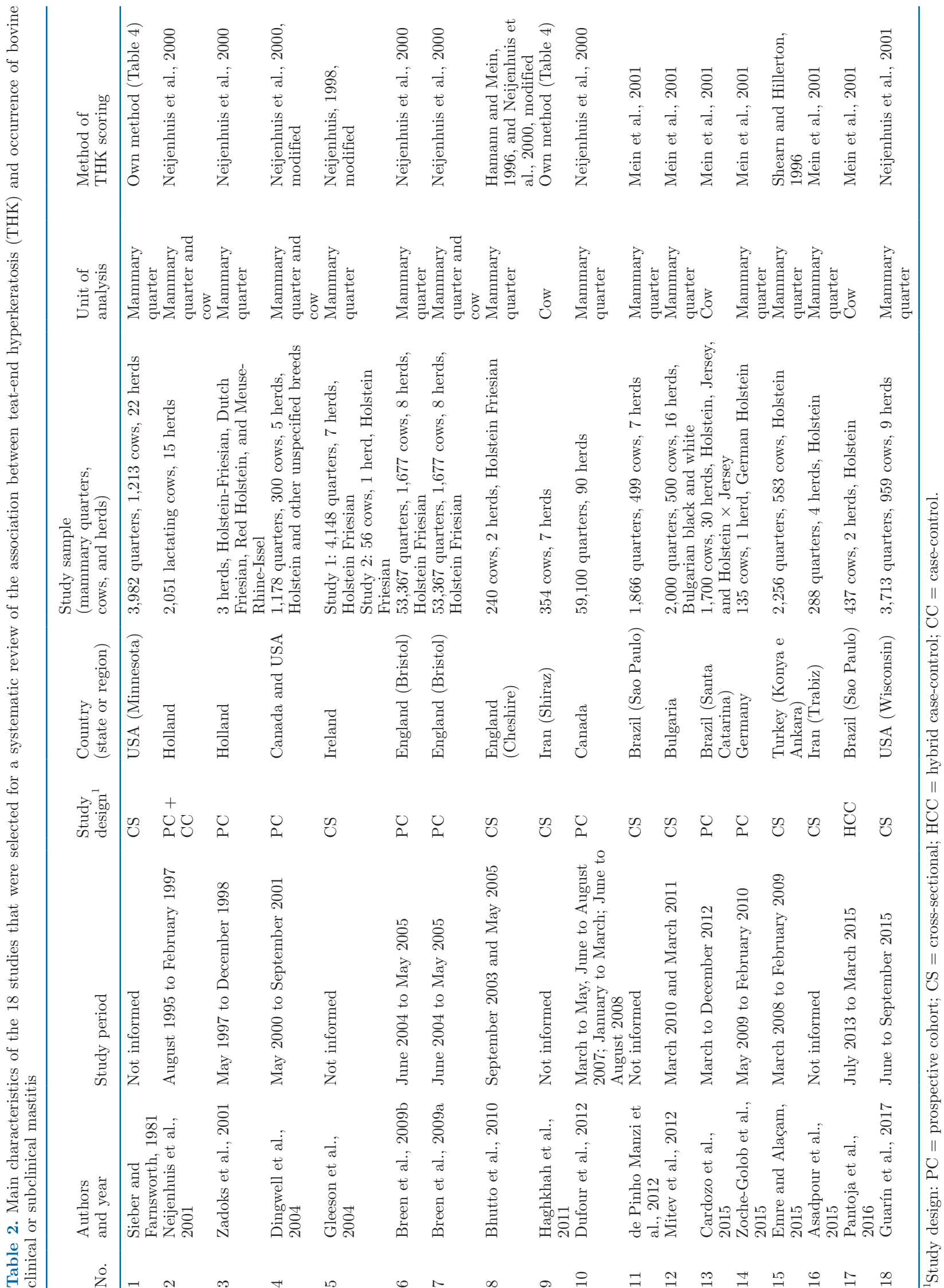


Table 3. Case definition for mastitis outcomes described in the 18 studies that were selected for a systematic review of the association between teat-end hyperkeratosis and occurrence of bovine clinical or subclinical mastitis

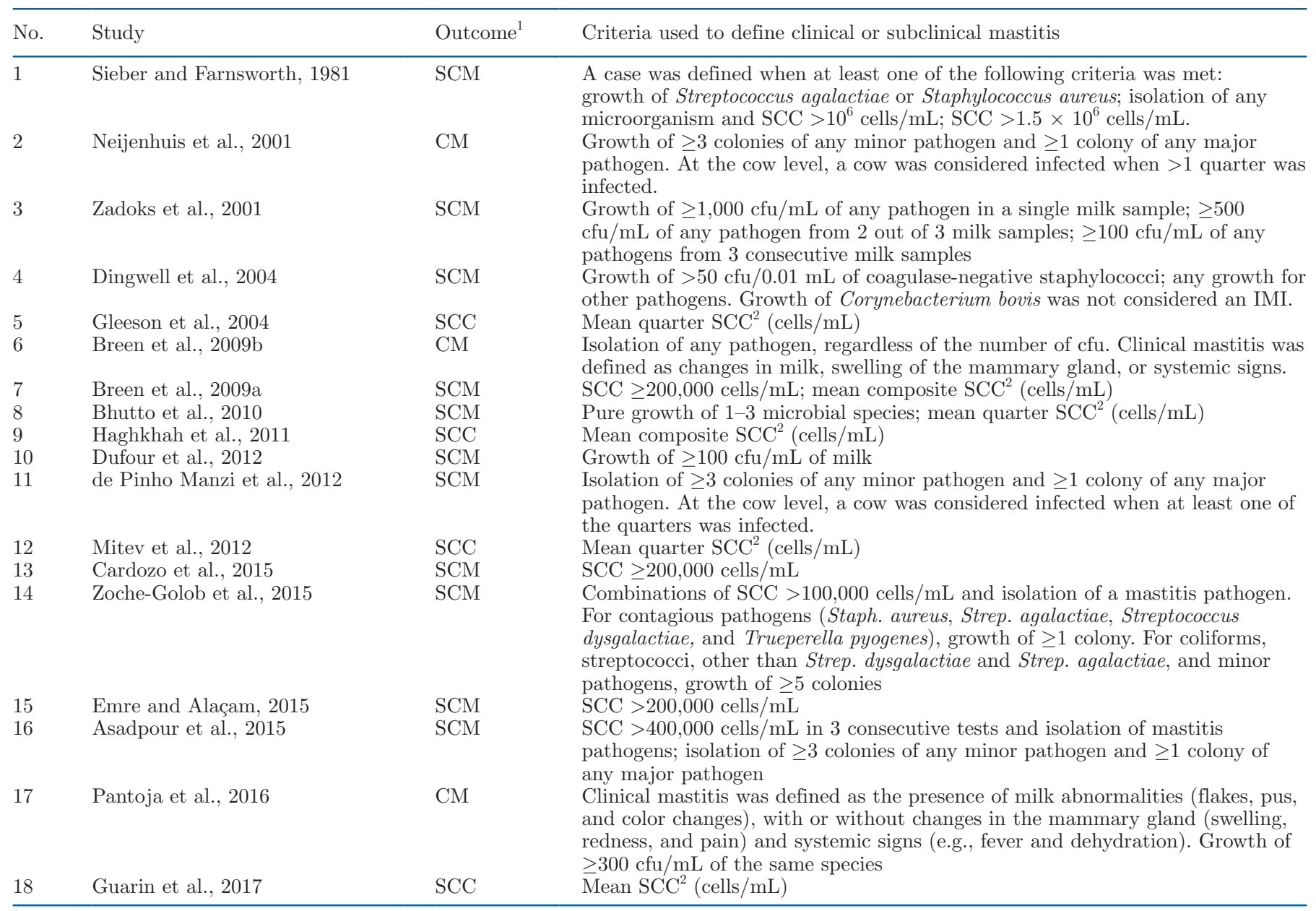

${ }^{1}$ Outcomes: $\mathrm{CM}=$ clinical mastitis; $\mathrm{SCM}=$ subclinical mastitis, as defined by microbiological examination of milk, SCC thresholds, or a combination of microbiological examination of milk and SCC thresholds; SCC = SCC as a continuous variable.

${ }^{2} \mathrm{~A}$ case was not defined because the outcome was SCC (continuous variable).

modeling and did not consider confounders and covariates.

\section{RESULTS}

\section{Study Characteristics}

Eighteen articles were included in this systematic review, of which 8 were prospective cohort studies, 9 were cross-sectional, and 1 was a hybrid case-control study (Table 2). Most studies $(\mathrm{n}=9)$ were conducted in Europe, 3 in South America, 4 in North America, and 2 in Asia (Table 2).

Thirteen studies analyzed only at quarter level, 2 at quarter and cow levels, and 3 only at cow level (Table 2 ). Different measures of association were used to quantify the relationship between THK and CM or SCM.
Difference between proportions was used in 4 studies (Sieber and Farnsworth, 1981; Bhutto et al., 2010; Asadpour et al., 2015; Emre and Alaçam, 2015), difference between means or linear regression was used in 7 studies (Neijenhuis et al., 2001; Gleeson et al., 2004; Bhutto et al., 2010; Haghkhah et al., 2011; de Pinho Manzi et al., 2012; Mitev et al., 2012; Guarin et al., 2017), odds ratio in 7 studies (Dingwell et al., 2004; Breen et al., 2009a,b; de Pinho Manzi et al., 2012; Dufour et al., 2012; Cardozo et al., 2015; Pantoja et al., 2016), and risk ratio in 2 studies (Zadoks et al., 2001; Zoche-Golob et al., 2015).

\section{Assessment of Validity and Reporting}

Six studies addressed $<30 \%$ of STROBE items (Sieber and Farnsworth, 1981; Gleeson et al., 2004; Bhutto et 
al., 2010; Haghkhah et al., 2011; de Pinho Manzi et al., 2012; Asadpour et al., 2015; Table 5). The STROBE items most frequently neglected were lack of sample size calculation, generalization of results, and study limitations. Only 6 studies reported $>90 \%$ of STROBE items. The main limitation of the reviewed studies was improper use of statistical methods to avoid confounding and biased estimates (Table 5). Mean validity score was 3.7 (minimum $=1.4$, maximum $=5.9$; Table 5$)$.

\section{Definition of Mastitis Outcomes and THK}

Mastitis outcomes (Table 3) used in the reviewed studies were (1) CM, defined based on clinical signs (with or without microbiological examination of milk; $\mathrm{n}=3$ ); (2) SCM, defined based on microbiological examination of milk $(\mathrm{n}=5)$; (3) SCM, defined based on SCC thresholds $(\mathrm{n}=3)$; (4) SCM, defined based on a combination of microbiological examination of milk and SCC ( $\mathrm{n}=3)$; and (5) mean SCC ( $\mathrm{n}=7$ studies). Teat-end hyperkeratosis was scored by use of different methods, of which the most frequent were proposed by
Neijenhuis et al. (2000; 39\%, $\mathrm{n}=7$ ) and Mein et al. (2001; $33 \%, \mathrm{n}=6$ studies; Tables 2 and 4 ).

\section{Association Between THK and CM}

Three studies investigated the association between THK and CM (Neijenhuis et al., 2001; Breen et al., 2009b; Pantoja et al., 2016). Neijenhuis et al. (2001; prospective cohort with validity score $=5.6$ ) compared THK scores between quarters that experienced CM and contralateral quarters of the same cow that did not experience CM (cross-sectional analysis) and reported positive associations that were not statistically significant. In addition, the authors performed longitudinal data analyses and reported that THK thickness of quarters that had CM was, on average, 0.13 and 0.08 units greater than that of quarters that did not have $\mathrm{CM}$ in the third month before the case, or within the month of the case, respectively. At cow level, although the authors reported that changes in THK score during lactation were associated with occurrence of $\mathrm{CM}$, data were presented in graphical format.

Table 4. Methods for classification of teat-end hyperkeratosis (THK) described in 18 studies that were selected for a systematic review of the association between THK and occurrence of bovine clinical or subclinical mastitis

\begin{tabular}{|c|c|c|}
\hline Study & $\begin{array}{l}\text { Number } \\
\text { of studies }\end{array}$ & Classification of THK \\
\hline Neijenhuis et al., 2000 & 7 & $\begin{array}{l}\mathrm{N}=\text { no ring; } 1 \mathrm{~A}=\text { thin } \text { ring, smooth; } 1 \mathrm{~B}=\text { moderate ring, smooth } 1 \mathrm{C}=\text { thick ring, } \\
\text { smooth; } 2 \mathrm{~A}=\text { thin ring, rough } 2 \mathrm{~B}=\text { moderate ring, rough; } 2 \mathrm{C}=\text { thick ring, rough; } \\
2 \mathrm{D}=\text { extremely thick ring, rough }\end{array}$ \\
\hline Mein et al., 2001 & 7 & $\begin{array}{l}1 \text { (no ring) = a typical status for many teats soon after the start of lactation; } 2 \\
\text { (smooth or slightly rough ring) = a raised ring with no roughness or only mild } \\
\text { roughness and no keratin fronds; } 3 \text { (rough ring) = a raised roughened ring with } \\
\text { isolated fronds of old keratin extending } 1-3 \mathrm{~mm} \text { from the teat orifice; } 4 \text { (very rough } \\
\text { ring) = a raised ring with rough fronds of old keratin extending }>4 \mathrm{~mm} \text { from the teat } \\
\text { orifice }\end{array}$ \\
\hline Sieber and Farnsworth, 1981 & 1 & $\begin{array}{l}1 \text { (normal) = smooth, nonraised, and well-closed orifice; } 2 \text { (smooth, chronic ring) }= \\
\text { smooth ring of tissue around teat orifice, with further classification as very mild, mild, } \\
\text { moderate, or severe; } 3 \text { (rough, chronic ring) = proliferative ring of tissue around teat } \\
\text { orifice, with further classification as very mild, mild, moderate, or severe; } 4 \text { (acute) = } \\
\text { ulcerative or hemorrhagic appearance to teat orifice, with or without a scab }\end{array}$ \\
\hline $\begin{array}{l}\text { Shearn and Hillerton, } \\
1996\end{array}$ & 1 & $\begin{array}{l}0 \text { (perfect orifice) = normal orifice, no dislocations, extrusions, or growths. Frequently, } \\
\text { a smooth ring exists that may be pigmented; } 1 \text { (slight hyperkeratosis) = smooth ring } \\
\text { that is slightly degenerate with a few minor crevices caused by radial cracking of the } \\
\text { keratin. There is slight hypertrophy of the keratin, especially if a keratinous ring exists } \\
\text { but no evidence of keratin extruding; } 2 \text { (moderate hyperkeratosis) = hypertrophy } \\
\text { has developed fronds of keratin extruding up to } 2 \text { mm from at least part of the } \\
\text { circumference. Only a few unpigmented fronds or pigmented keratin might affect three- } \\
\text { quarters of the orifice; } 3 \text { (moderate to severe hyperkeratosis) = extruding fronds are } \\
\text { immediately obvious, affecting the whole circumference of the orifice and extruding } \\
\text { for } 1-3 \text { mm. The pigmentation does not affect the score; } 4 \text { (severe hyperkeratosis) } \\
=\text { fronds are very pronounced, usually extending beyond the orifice by } 3-4 \text { mm, and } \\
\text { obscure the rest of the orifice; } 5 \text { (very severe hyperkeratosis) = the whole orifice } \\
\text { appears significantly enlarged with fronds }>4 \text { mm long. }\end{array}$ \\
\hline Bhutto et al., 2010 & 1 & $\begin{array}{l}\text { Based on the scales proposed by Hamann and Mein (1996) and Neijenhuis et al. } \\
(2000) \text {, teat ends were classified into } 0=\text { normal, no lesions; } 1=\text { smooth, slightly } \\
\text { rough ring; } 2=\text { rough chronic ring; or } 3=\text { very rough, severely hyperkeratotic. }\end{array}$ \\
\hline Haghkhah et al., 2011 & 1 & Rough; very rough \\
\hline
\end{tabular}


Breen et al. (2009b; prospective cohort with validity score $=5.9)$ reported that only severe THK was associated with increased odds of CM. The odds of the first case of CM in lactation were 2.67 times greater $(95 \%$ $\mathrm{CI}=1.50-4.74)$ for quarters with teats scored as $2 \mathrm{D}$ (severe THK, scale by Neijenhuis et al., 2000; Table 4 ), as compared with quarters with teats scored as $\mathrm{N}$ to $2 \mathrm{C}$ (combined in a single category). The odds of CM (regardless of order in lactation) were 2.28 times greater $(95 \% \mathrm{CI}=1.50-3.96)$ for quarters with teats scored as $2 \mathrm{D}$ than for quarters with teats scored as N to $2 \mathrm{C}$. The odds of CM caused by E. coli and Strep. uberis were $6.01(95 \% \mathrm{CI}=2.56-14.13)$ and $4.32(95 \%$ $\mathrm{CI}=1.32-14.13)$ times greater for quarters with teats scored as 2D than for quarters with teats scored as $\mathrm{N}$ to $2 \mathrm{~A}$ (E. coli) or $1 \mathrm{~A}$ to $2 \mathrm{C}$ (Strep. uberis), respectively.

Pantoja et al. (2016; hybrid case-control with validity score $=4.7)$ evaluated risk factors for the second case of $\mathrm{CM}$ during the same lactation. When not adjusting for confounding factors, the proportion of cows with THK score $=4$ (scale by Mein et al., 2001, Table 4) was 2.2 times greater for cows that experienced the second case of CM $(25.6 \%)$ as compared with cows that did not experience CM (11.4\%). However, when parity (confounding factor) was considered in the analysis, the association between THK and occurrence of CM was still positive but no longer significant.

\section{Association Between THK and SCM, as Defined by Microbiological Examination of Milk}

Five studies evaluated the association between THK and SCM, as defined by microbiological examination of milk (Zadoks et al., 2001; Dingwell et al., 2004; Bhutto et al., 2010; de Pinho Manzi et al., 2012; Dufour et al., 2012), of which 3 reported a significant positive association between severe THK and Staph. aureus IMI. Dufour et al. (2012; prospective cohort with validity score $=5.9)$ reported that the odds of a new Staph. aureus $\mathrm{IMI}$ were $2.1(95 \% \mathrm{CI}=1.0-4.5)$ and $3.7(95 \% \mathrm{CI}$ $=1.6-8.8)$ times greater for quarters with teats scored as $2 \mathrm{C}$ and $2 \mathrm{D}$ (severe THK, scale by Neijenhuis et al., 2000; Table 4) than for quarters with no THK, respectively. Other THK scores were not associated with the incidence of Staph. aureus. The authors also performed cross-sectional analyses, in which the chances of Staph. aureus IMI were $1.9(95 \% \mathrm{CI}=1.1-3.4)$ and $4.7(95 \%$ $\mathrm{CI}=2.4-9.2)$ times greater for quarters with teats

Table 5. Validity scores for the 18 studies that were selected for a systematic review of the association between teat-end hyperkeratosis (THK) and occurrence of bovine clinical or subclinical mastitis

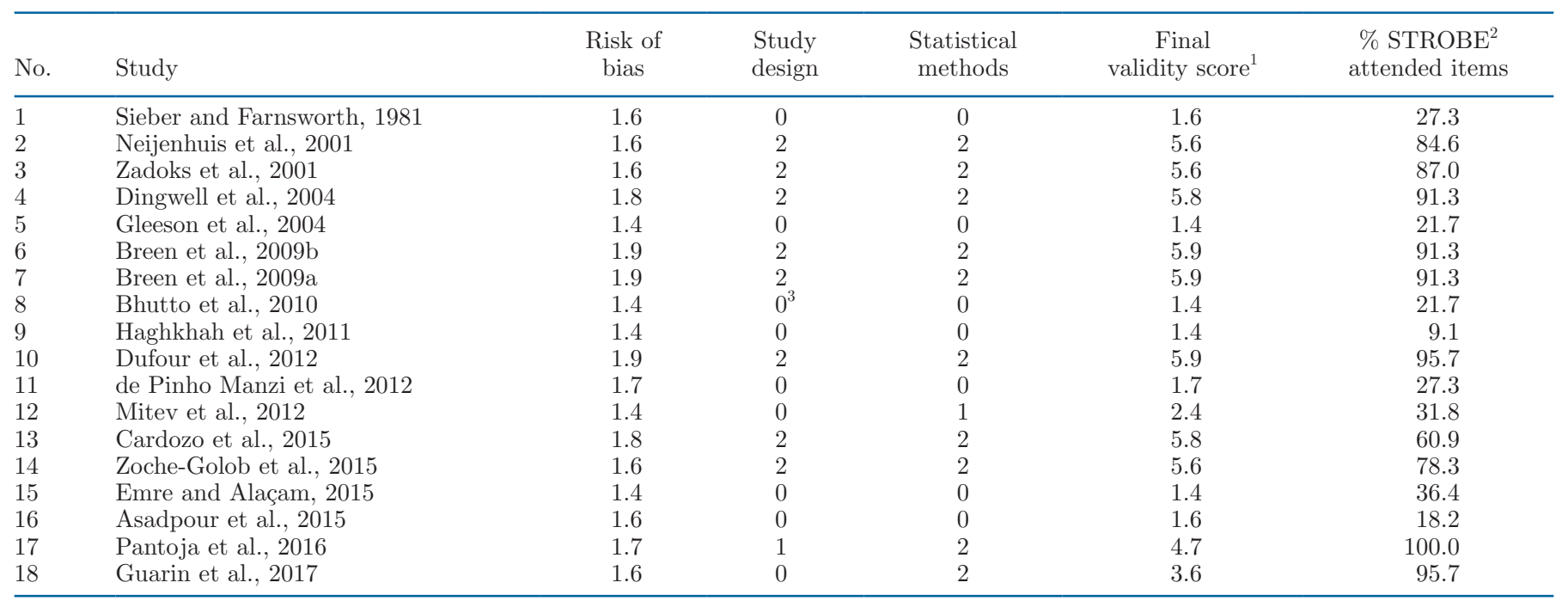

${ }^{1}$ The final validity score ranged from 0 to 6 and was based on study design, risk of bias, and statistical methods. Scores given to each of the 3 criteria ranged from 0 (least strength of evidence) to 2 (greatest strength of evidence). Scores given to each criterion were then added to assign a final score. Cohort, case-control, and cross-sectional studies were given scores 2, 1, and 0, respectively, based on strength of evidence. Risk of introducing outcome (clinical or subclinical mastitis) and exposure (THK) biases was scored according to the Newcastle-Ottawa scale for assessing the quality of nonrandomized studies in meta-analyses (Wells et al., 2014). The statistical methods score was defined as follows: $2=$ use of proper multivariable modeling to account for covariates and confounders, accounted for repeated measurements or lack of independence between quarters within cow or cows within herd; 1 = did not use multivariable modeling but accounted for confounders to some extent, such as use of stratified analysis, or used multivariable modeling without considering repeated measurements or lack of independence between quarters within cow or cows within herd; and $0=$ did not use multivariable modeling and did not consider confounders and covariates.

${ }^{2} \mathrm{STROBE}=$ strengthening the reporting of observational studies in epidemiology (Sargeant et al., 2016).

${ }^{3}$ Prospective cohort with cross-sectional data analysis. 
scored as $2 \mathrm{C}$ and $2 \mathrm{D}$ than for quarters with no THK, respectively. Other THK scores were not associated with Staph. aureus IMI (Dufour et al., 2012).

Similarly, Zadoks et al. (2001; prospective cohort with validity score $=5.6$ ) reported, at quarter level, that only severe THK was significantly associated with new Staph. aureus IMI. The incidence rate of Staph. aureus $\mathrm{IMI}$ was 5.05 (95\% CI $=2.14-11.94)$ times greater for quarters with severe THK thickness (2D, scale by Neijenhuis et al., 2000, Table 4) than for quarters with absent or thin THK combined. Quarters with teats scored as rough $(2 \mathrm{~A}-2 \mathrm{D})$ and concomitant isolation of Corynebacterium spp. experienced an incidence rate of Staph. aureus IMI $9.49(95 \% \mathrm{CI}=1.36-66.02)$ times greater than quarters with no THK. The incidence rate was not different between quarters with moderate and no THK.

Bhutto et al. (2010; cross-sectional study with validity score $=1.4$ ) reported that the proportion of quarters infected with Staph. aureus was greater (38.3\%) for quarters with severe THK (scale modified from Hamann and Mein, 1996; Neijenhuis et al., 2000; Table 4) than for quarters with a rough teat-end ring (13\%) or slightly rough teat-end ring $(12.7 \%)$ or those with no THK (21\%). The proportion of quarters infected with Staph. aureus was greater for quarters with no THK as compared with quarters with a smooth teatend ring. The proportion of quarters infected with $E$. coli was greater $(34.2 \%)$ in quarters with severe THK than in those with rough teat-end ring (15.9\%), mild ring $(7.8 \%)$, or no THK $(7.9 \%)$. The study received a low statistical methods score because of confounding factors (such as parity and DIM), and possible lack of independence among observations was not considered in the analyses.

Dingwell et al. (2004; prospective cohort with validity score $=5.8$ ) assessed cow and quarter risk factors for IMI across the dry period and observed that quarters with cracked teat ends were $1.7(95 \% \mathrm{CI}=1.0-2.7)$ times more likely to develop new postpartum IMI than quarters with no THK. At cow level, cows that had at least one cracked teat end at dry off were 2.5 (95\% CI = 1.1-5.4) times more likely to develop a new postpartum IMI. Although the scoring method was by Neijenhuis et al. (2000), scores were dichotomized for analyses (with or without cracking).

de Pinho Manzi et al. (2012; cross-sectional study with validity score $=1.7$ ) reported that the odds of IMI at the quarter level were $1.31(95 \% \mathrm{CI}=1.17-1.47)$ times greater for every 1-unit increase in THK score (scale by Mein et al., 2001). However, parity and other confounding factors, as well as lack of independence among observations, were not considered in the multivariable analyses.

\section{Association Between THK and SCM, as Defined by a Combination of Microbiological Examination of Milk and SCC}

None of the 3 studies that used a combination of microbiological examination of milk and SCC thresholds as SCM outcomes reported significant associations with THK (Sieber and Farnsworth, 1981; Asadpour et al., 2015; Zoche-Golob et al., 2015). In the study conducted by Zoche-Golob et al. (2015; prospective cohort with score $=5.6)$, no effect of THK was observed on the risk of new IMI. Likewise, Asadpour et al. (2015) and Sieber and Farnsworth (1981; both cross-sectional studies with validity score $=1.6$ ) did not find significant associations between THK and SCM. Both cross-sectional studies had analytical limitations, such as not accounting for confounding factors and possible lack of independence among observations.

\section{Association Between THK and SCM, as Defined by SCC Thresholds}

Three studies investigated the association between THK and SCM, as defined by use of SCC thresholds. Breen et al. (2009a; prospective cohort with validity score $=5.9$; THK scale by Neijenhuis et al., 2000) observed that quarters with teats scored as $1 \mathrm{~A}$ [odds ratio $(\mathbf{O R})=0.77,95 \% \mathrm{CI}=0.63-0.94], 1 \mathrm{~B}(\mathrm{OR}=$ $0.70,95 \% \mathrm{CI}=0.56-0.87), 1 \mathrm{C}(\mathrm{OR}=0.60,95 \% \mathrm{CI}$ $=0.44-0.81), 2 \mathrm{~A}(\mathrm{OR}=0.65,95 \% \mathrm{CI}=0.50-0.84)$, and $2 \mathrm{~B}(\mathrm{OR}=0.62,95 \% \mathrm{CI}=0.47-0.84)$ were less likely to be reported with $\mathrm{SCC} \geq 200,000$ cells/mL at the next monthly SCC test day than quarters with no THK, suggesting a protective effect. Severe THK (score $2 \mathrm{C}$ or $2 \mathrm{D}$ ) were not associated with the odds of SCC $\geq 200,000$ cells $/ \mathrm{mL}$.

In contrast, Cardozo et al. (2015; prospective cohort with validity score $=5.8$ ) investigated risk factors for new SCM using monthly SCC values. The odds of SCC $\geq 200,000$ cells $/ \mathrm{mL}$ at the next monthly test day were $1.61(95 \% \mathrm{CI}=1.12-2.31)$ times greater for cows with mean THK score $=4$ (scale by Mein et al., 2001) as compared with cows with mean THK score of 1 to 3 .

Emre and Alaçam (2015; cross-sectional study with validity score $=1.4$ ) reported that 20.4, 30.5, and $39.1 \%$ of quarters scored with no THK (scale by Shearn and Hillerton, 1996), moderate THK (scores 1 and 2), and severe THK (scores 3, 4, and 5) had SCC $>200,000$ cells $/ \mathrm{mL}$, respectively. The study received a low statistical methods score due to analyses that were not adjusted by parity (although parity was associated with hyperkeratosis), and lack of methods to account for possible clustering of quarters within cows (Table $5)$. 


\section{Association Between THK and SCC, as a Continuous Outcome}

Seven studies (Gleeson et al., 2004; Bhutto et al., 2010; Haghkhah et al., 2011; de Pinho Manzi et al., 2012; Mitev et al., 2012; Asadpour et al., 2015; Guarin et al., 2017) investigated the association between THK and mean SCC. Guarin et al. (2017; cross-sectional study with validity score $=3.6$ ) reported that mean SCC of quarters with severe THK (score 4, scale by Mein et al., 2001) was greater $(104,232)$ than that of quarters with no THK $(47,534$ cells $/ \mathrm{mL})$, regardless of parity and DIM. Mean SCC of quarters with teats scored as 2 was lower $(41,400)$ than that of quarters with no THK $(47,534$ cells $/ \mathrm{mL})$.

Gleeson et al. (2004; cross-sectional study with validity score $=1.4$ ) conducted 2 studies in Ireland and reported that mean SCC was not different among quarters with different THK scores. In contrast, for a subset of quarters that were not treated with postdipping during lactation, mean SCC was greater $(412,000)$ for quarters scored as 3 or 4 (scale modified by Neijenhuis, 1998) than for quarters scored as $2(306,000$ cells $/ \mathrm{mL})$. This study received a low statistical methods score (Table 5) because possible confounding factors, such as parity, DIM, and milk production, were not considered in the analyses.

In the study conducted by Haghkhah et al. (2011; cross-sectional study with validity score $=1.4)$, mean SCC of quarters with teats scored as abnormal (659.01 \pm 120.17 ) was significantly greater than that of quarters with no THK $(372.67 \pm 57.20$ cells $/ \mathrm{mL})$. However, means were not adjusted for confounding factors, and SCC data were not normalized, which may have overestimated the mean values.

Three studies that received low validity score found a positive association between THK and SCC. Mitev et al. (2012; cross-sectional study with validity score $=2.4$ ) reported that mean SCC was $140,000,160,000$, 195,700 , and 235,400 cells $/ \mathrm{mL}$ for quarters with teats scored as 1, 2, 3, and 4, respectively (scale by Mein et al., 2001). Similarly, Asadpour et al. (2015; crosssectional study with validity score $=1.6$ ) found a positive linear correlation between THK and SCC ( $\mathrm{r}$ $=0.24$ ). There was an increase of 103.56 cells $/ \mathrm{mL}$ in mean SCC for each 1-unit increase in THK score. Both studies were analytically limited in that SCC data were not normalized and estimates were not adjusted for confounding factors.

In the study by de Pinho Manzi et al. (2012), mean SCC varied significantly among different THK scores. Milk of quarters with teats scored as 2 (scale by Mein et al., 2001) had lower ln SCC (2.29; 95\% CI = 2.14-2.44) than quarters with teats scored as $1(2.66 ; 95 \% \mathrm{CI}=$ $2.49-2.82), 3(2.72 ; 95 \%$ CI $=2.59-2.84)$, or 4 (2.70; $95 \%$ CI $=2.56-2.84)$, suggesting that a smooth teatend ring with no keratin fronds could have a protective effect. However, mean estimates were not adjusted for possible confounding variables, and clustering of teats within cows was not considered. Bhutto et al. (2010; cross-sectional study with validity score $=1.4$ ) reported no mean SCC difference among quarters with different THK scores.

\section{DISCUSSION}

The aim of this systematic review was to elucidate the role of THK as a risk factor for CM or SCM (the latter assessed using microbiology, SCC, or both). Only 18 studies qualified for inclusion, and most had relevant issues of internal validity, compromising the strength of evidence. Another point of difficulty was the variety of methods used to define THK, CM, and SCM, making it difficult to compare studies and perform meta-analysis. Nonetheless, some valid conclusions can be drawn from the studies with higher internal validity.

When comparing studies, it has been increasingly suggested that the biological nature of associations be given as important as the statistical significance of the findings (Amrhein et al., 2019). Thus, the 3 studies that used CM as outcome produced data that show a positive association with THK, although the magnitude and statistical significance of the estimates differed among them. Two studies (Neijenhuis et al., 2001; Pantoja et al., 2016) showed biologically weak to moderate associations between THK and CM, but their multivariable analyses demonstrated that parity is an important confounder for this association. Breen et al. (2009b) reported that only severe THK was associated with environmental (E. coli or Strep. uberis) or contagious (Staph. aureus) CM, suggesting moderate to strong effects, depending on the pathogen involved. Three studies (all with high validity scores) established a clear temporal relationship between THK and CM, which supports a causal effect. The different magnitude and statistical significance of the findings (measures of association) may be explained by factors such as sample size and THK scoring method. When THK is categorized in several levels (e.g., scale by Mein et al., 2001), the sample size within some categories, such as "very rough," often results in sparse data, decreasing precision of estimates and probability of finding statistically significant results. When THK is analyzed as a continuous variable and used as an explanatory variable, a further issue is that the relationship with $\mathrm{CM}$ is possibly not linear, because evidence exists that milk 
THK has a protective effect (as discussed in the following topics). In addition, CM may be an infrequent outcome in longitudinal studies, making it difficult to obtain large sample sizes. Despite these difficulties, the little available evidence suggests (based on biological and statistical interpretation of findings) that THK (especially severe) is a risk factor for CM.

Likewise, most studies that used SCM as the primary outcome (based on microbiological examination of milk) reported that only severe THK was associated with SCM. Two studies with high validity scores reported moderate to strong associations between severe THK and incidence or prevalence of Staph. aureus IMI, emphasizing the importance of teat-end health for control of contagious mastitis. It is important to note that both were cohort studies in which a clear temporal relationship could be stablished between THK and new Staph. aureus IMI, regardless of the effect of confounders such as parity and DIM. Thus, the available evidence indicates that severe THK is a strong risk factor for Staph. aureus IMI.

When SCC (thresholds or mean) or a combination of microbiological examination of milk and SCC thresholds were used to identify SCM, most studies reported positive associations with THK. Three studies (Gleeson et al., 2004; Breen et al., 2009a; Bhutto et al., 2010) reported no association between THK and SCC. In contrast, 2 studies with high validity scores (Cardozo et al., 2015; Guarin et al., 2017) reported that only severe THK was associated the risk of SCC $\geq 200,000$ cells $/ \mathrm{mL}$ and increased mean SCC, respectively. Likewise, one cohort study with high validity score (Dingwell et al., 2004) also reported that cows with cracked teat ends at dry-off were more likely to develop new postpartum SCM. Although 4 cross-sectional studies reported positive associations between THK and SCC, it is possible that the associations were spurious because confounding factors were not considered in their analysis. Thus, although differences existed in statistical significance and precision, evidence from the reviewed studies suggests that mostly severe THK is a risk factor for SCM, as defined by SCC thresholds or mean SCC.

Interestingly, 4 studies (Breen et al., 2009a; Bhutto et al., 2010; de Pinho Manzi et al., 2012; Guarin et al., 2017) demonstrated that quarters with mild THK (score 2 by Mein et al., 2001) had lower prevalence of IMI or lower mean SCC than quarters with no THK. Development of mild THK at the teat end is a natural physiological response to the action of milking equipment; thus, results of these studies suggest that mild THK, as a physiological response to milking, can be somehow a protective barrier against mastitis pathogens. More research is necessary to elucidate such a mechanism.

\section{Internal Validity}

Relevant validity issues were found in most reviewed studies. The main analytical issue was lack of appropriate multivariable analyses. All articles included in this review were observational, highlighting the importance of using proper statistical methods. Most studies were prospective cohorts, that is, cows or quarters with different THK scores were followed over time to capture incidence of $\mathrm{CM}$ or SCM. Other studies were crosssectional, in which THK and CM or SCM were assessed at a fixed point in time (farm visit day). Because both THK and chronic SCM can be of long duration, cross-sectional studies are more limited in determining whether THK occurred before CM or SCM.

The main validity issue was to neglect factors that can confound the association between THK and CM or SCM. Parity is associated with CM or SCM in cows with no THK (i.e., is an independent risk factor for mastitis), parity is also associated with THK, and parity is not a consequence of THK, therefore meeting all classic confounding criteria (Dohoo et al., 2009). If such factors are not considered in the analysis, spurious associations can be produced. For example, Pantoja et al. (2016) reported a significant, strong association between THK and CM as a result of bivariate analyses. However, the association was no longer significant when adjusted by parity. Parity is an important risk factor for THK, older cows have greater prevalence of THK due to teat dimensions and longer exposure to milking equipment (Neijenhuis et al., 2000; Sandrucci et al., 2014).

Besides parity (Sandrucci et al., 2014; Pantoja et al., 2016), several factors have been associated with THK, such as teat shape and position (Neijenhuis et al., 2000; Tancin et al., 2006), machine-on time (Neijenhuis et al., 2000; Zucali et al., 2008), and stage of lactation (Neijenhuis et al., 2001). It is well documented in the scientific literature that most of these risk factors for THK are also associated with CM or SCM occurrence (Peeler et al., 2000; Oliveira et al., 2015) and can, therefore, confound the association between THK and CM or SCM. Thus, associations between THK and SCM reported in several studies (Gleeson et al., 2004; Haghkhah et al., 2011; Mitev et al., 2012; Asadpour et al., 2015; Emre and Alaçam, 2015) could be spurious due to confounding. It should be noted that the scientific papers with low validity were peer-reviewed and accepted for publication, highlighting that scientific methodology can be an issue for the dairy science academic community. Publication of such studies can have a negative effect in the field because dairy professionals tend to trust scientific publications and may not be aware that results can be invalid. 


\section{External Validity of the Studies}

In the reviewed studies, THK was assessed in herds that were mostly composed of Holstein cows at any stage of lactation and housed in confinement systems, such as freestall barns. We believe that results found in these studies can be extrapolated to dairy herds with similar characteristics anywhere in the world.

\section{Definition of Mastitis Outcomes and THK}

One relevant issue that prevented meta-analysis of the data and comparability among studies was the different definitions used for THK, CM, and SCM. At least 5 different methods were used to define THK scores. In addition, some studies combined scores into 2 or more categories for analysis. For example, in the study by Dingwell et al. (2004), although THK was scored according to Neijenhuis et al. (2000), with modifications, data were dichotomized for analysis (with and without cracks). Use of multilevel THK scores that were analyzed as ordinal scales, as proposed by Neijenhuis et al. (2000), probably resulted in lack of power to find significant associations, due to the small sample size within each THK score (e.g., Breen et al., 2009b). We believe that adoption of scales with fewer categories and that are easier to perform in the field, such as that proposed by Mein et al. (2001), should be encouraged.

Microbiological examination of milk has been considered a reference test for diagnosing $\mathrm{CM}$ and SCM, because it allows identification of the causative agent. Nonetheless, criteria used to define IMI varied widely among studies, ranging from different detection limits (e.g., 100 to $500 \mathrm{cfu} / \mathrm{mL}$ of milk) to associations with SCC, and use of single or a series of milk samples. Although such definitions can affect test accuracy, it should not have resulted in bias because, in all studies, the same case definition was applied to all exposure groups (e.g., quarters with different THK scores). The same principle applies to SCC, for which sensitivity and specificity can vary according to the threshold, pathogen involved, and type of milk sample (Dohoo and Leslie, 1991). The main consequence of the different CM and SCM definitions used across studies was lack of comparability, which prevented us from meta-analyzing the data.

\section{Limitations in Study Reporting (STROBE)}

Due to limitations of observational studies, guidelines have been created to standardize reporting and facilitate evaluation of articles (Sargeant et al., 2016). Most reviewed studies did not meet most STROBE items, which made it difficult to understand and assess both internal and external validity. Sample size calculation is one of the items recommended by STROBE that is critical to assess statistical power, although it was only reported in one study. It is important that authors of observational studies report the key items recommended by STROBE, to facilitate understanding of the methodology and correct interpretation of results.

\section{Limitations of the Systematic Review}

Only articles published in English were included in this systematic review, which may have excluded relevant articles published in other languages. Seven eligible studies were not identified in our initial search and were only found by screening of references. Thus, the search strategy possibly had limitations, such as lack of terms used to identify mastitis (e.g., "intramammary infection" or names of specific mastitis pathogens). In addition, some conclusions of this review, mostly regarding the association between THK and CM, are based on few studies. More sound research is necessary to better investigate this association.

\section{CONCLUSIONS}

Results of the reviewed studies suggest that severe THK is a risk factor for both CM and SCM, as defined by microbiological examination of milk, SCC thresholds, or mean SCC. The effect of severe THK on both contagious (especially Staph. aureus) and environmental CM or SCM emphasizes the importance of teat health for mastitis control. Associations between THK and SCM reported in several studies could be spurious, because confounding factors (such as parity) were not considered in the analyses. Mild THK, as a physiological response to milking, can be protective against SCM. Future research should consider standardization of methods to define THK, CM, and SCM. At the farm level, dairy consultants should focus on monitoring and minimizing occurrence of severe THK to prevent CM and SCM.

\section{ACKNOWLEDGMENTS}

This study was funded with resources from the Sao Paulo State University's Mastitis Research and Diagnostic Laboratory (Botucatu, Sao Paulo, Brazil). The scholarship of Giulia S. Latosinski (2017/205765) was funded by the Sao Paulo Research Foundation (FAPESP, SP, Brazil). The scholarships of Rodolfo S. Rossi (132538-2015-6) and Leticia B. N. Correia (164827/2015-3) were funded by the National Council 
for Scientific and Technological Development (CNPQ, Brasilia, DF, Brazil).

\section{REFERENCES}

Amrhein, V., S. Greenland, and B. McShane. 2019. Scientists rise up against statistical significance. Nature 567:305-307. https://doi .org/10.1038/d41586-019-00857-9.

Asadpour, R., H. Bagherniaee, M. Houshmandzad, H. Fatehi, A. Rafat, K. Nofouzi, and K. Maftouni. 2015. Relationship between teat end hyperkeratosis with intra mammary infection and somatic cell counts in lactating dairy cattle. Rev. Med. Vet. 166:266-270.

Bhutto, A. L., R. D. Murray, and Z. Woldehiwet. 2010. Udder shape and teat-end lesions as potential risk factors for high somatic cell counts and intra-mammary infections in dairy cows. Vet. J. 183:63-67. https://doi.org/10.1016/j.tvjl.2008.08.024.

Blowey, R. W., and A. D. Weaver. 2011. Udder and teat disorders. Pages 205-219 in Color Atlas of Diseases and Disorders of Cattle. 3rd ed. Mosby Elsevier, New York, NY.

Breen, J. E., A. J. Bradley, and M. J. Green. 2009a. Quarter and cow risk factors associated with a somatic cell count greater than 199,000 cells per milliliter in United Kingdom dairy cows. J. Dairy Sci. 92:3106-3115. https://doi.org/10.3168/jds.2008-1562.

Breen, J. E., M. J. Green, and A. J. Bradley. 2006. Hyperkeratosis of the teat-end: Methods of assessment, interpretation of teat-end scores and relationship with clinical and sub-clinical mastitis. UK Vet. 11:1-6.

Breen, J. E., M. J. Green, and A. J. Bradley. 2009b. Quarter and cow risk factors associated with the occurrence of clinical mastitis in dairy cows in the United Kingdom. J. Dairy Sci. 92:2551-2561. https://doi.org/10.3168/jds.2008-1369.

Cardozo, L. L., A. Thaler Neto, G. N. Souza, L. C. Picinin, N. C. Felipus, N. L. Reche, F. A. Schmidt, D. Werncke, and E. E. Simon. 2015. Risk factors for the occurrence of new and chronic cases of subclinical mastitis in dairy herds in southern Brazil. J. Dairy Sci. 98:7675-7685. https://doi.org/10.3168/jds.2014-8913.

Dahl, M. O., F. P. Maunsell, A. De Vries, K. N. Galvao, C. A. Risco, and J. A. Hernandez. 2017. Evidence that mastitis can cause pregnancy loss in dairy cows: A systematic review of observational studies. J. Dairy Sci. 100:8322-8329. https://doi.org/10.3168/jds .2017-12711.

de Pinho Manzi, M., D. B. Nóbrega, P. Y. Faccioli, M. Z. Troncarelli, B. D. Menozzi, and H. Langoni. 2012. Relationship between teatend condition, udder cleanliness and bovine subclinical mastitis. Res. Vet. Sci. 93:430-434. https://doi.org/10.1016/j.rvsc.2011.05 .010 .

Dingwell, R. T., K. E. Leslie, Y. H. Schukken, J. M. Sargeant, L. L. Timms, T. F. Duffield, G. P. Keefe, D. F. Kelton, K. D. Lissemore, and J. Conklin. 2004. Association of cow and quarter-level factors at drying-off with new intramammary infections during the dry period. Prev. Vet. Med. 63:75-89. https://doi.org/10.1016/j .prevetmed.2004.01.012.

Dohoo, I., S. W. Martin, and H. Stryhn. 2009. Veterinary Epidemiologic Research. 2nd ed. VER Inc., Charlottetown, Prince Edward Island, Canada.

Dohoo, I. R., and K. E. Leslie. 1991. Evaluation of changes in somatic cell counts as indicators of new intramammary infections. Prev. Vet. Med. 10:225-237. https://doi.org/10.1016/0167 $-5877(91) 90006-\mathrm{N}$.

Dufour, S., I. R. Dohoo, H. W. Barkema, L. DesCôteaux, T. J. DeVries, K. K. Reyher, J. P. Roy, and D. T. Scholl. 2012. Manageable risk factors associated with the lactational incidence, elimination, and prevalence of Staphylococcus aureus intramammary infections in dairy cows. J. Dairy Sci. 95:1283-1300. https://doi.org/10.3168/ jds.2011-4711.

Emre, B., and E. Alaçam. 2015. The occurrence of teat hyperkeratosis in cows and its effect on milk somatic cell counts. Turkiye Klinikleri J. Vet. Sci. 6:1-6. https://doi.org/10.5336/vetsci.2012 -29182 .
Gleeson, D., W. Meaney, and E. O'Callaghan. 2004. Effect of teat hyperkeratosis on somatic cell counts of dairy cows. Int. J. Appl. Res. Vet. 2:115-122.

Guarín, J. F., M. G. Paixão, and P. L. Ruegg. 2017. Association of anatomical characteristics of teats with quarter-level somatic cell count. J. Dairy Sci. 100:643-652. https://doi.org/10.3168/jds.2016 -11459 .

Haghkhah, M., M. R. Ahmadi, H. R. Gheisari, and A. Kadivar. 2011. Preliminary bacterial study on subclinical mastitis and teat condition in dairy herds around Shiraz. Turk. J. Vet. Anim. Sci. 35:387394. https://doi.org/10.1590/S0034-89102010000300021.

Hamann, J., and G. A. Mein. 1996. Teat thickness changes may provide biological test for effective pulsation. J. Dairy Res. 63:179189. https://doi.org/10.1017/S002202990003168X.

Mein, G. A. 2012. The role of the milking machine in mastitis control. Vet. Clin. North Am. Food Anim. Pract. 28:307-320. https://doi .org/10.1016/j.cvfa.2012.03.004.

Mein, G. A., F. Neijenhuis, W. F. Morgan, D. J. Reinemann, E. Hillerton, J. R. Baines, I. Ohnstad, M. D. Rasmussen, L. Timms, J. S. Britt, R. Farnsworth, N. Cook, and T. Hemling. 2001. Evaluation of bovine teat condition in commercial dairy herds: 1 . Non-infectious factors. Pages 347-351 in AABB-NMC Int. Symp. Mastitis Milk Quality Proc., Vancouver, BC, Canada. National Mastitis Council, Madison, WI.

Mitev, J. E., I. Gergovska, and T. M. Miteva. 2012. Effect of teat end hyperkeratosis on milk somatic cell counts in Bulgarian black-andwhite dairy cattle. Bulg. J. Agric. Sci. 18:451-454.

Moher, D., A. Liberati, J. Tetzlaff, and D. G. Altman. 2009. Preferred reporting items for systematic reviews and meta-analyses: The PRISMA statement. Ann. Intern. Med. 151:264-269. https://doi .org/10.7326/0003-4819-151-4-200908180-00135.

Neijenhuis, F. 1998. Teat end callosity classification system. Pages 117-123 in Proc. 4th Intern. Dairy Housing Conf., St. Louis, MO. American Society of Agricultural Engineers.

Neijenhuis, F., H. W. Barkema, H. Hogeveen, and J. P. T. M. Noordhuizen. 2000. Classification and longitudinal examination of callused teat ends in dairy cows. J. Dairy Sci. 83:2795-2804. https:// doi.org/10.3168/jds.S0022-0302(00)75177-0.

Neijenhuis, F., H. W. Barkema, H. Hogeveen, and J. P. T. M. Noordhuizen. 2001. Relationship between teat-end callosity and occurrence of clinical mastitis. J. Dairy Sci. 84:2664-2672. https://doi .org/10.3168/jds.S0022-0302(01)74720-0.

Oliveira, C. S. F., H. Hogeveen, A. M. Botelho, P. V. Maia, S. G. Coelho, and J. P. A. Haddad. 2015. Cow-specific risk factors for clinical mastitis in Brazilian dairy cattle. Prev. Vet. Med. 121:297-305. https://doi.org/10.1016/j.prevetmed.2015.08.001.

Paduch, J. H., E. Mohr, and V. Krömker. 2012. The association between teat end hyperkeratosis and teat canal microbial load in lactating dairy cattle. Vet. Microbiol. 158:353-359. https://doi.org/ 10.1016/j.vetmic.2012.02.032.

Pantoja, J. C. F., A. P. Almeida, B. dos Santos, and R. S. Rossi. 2016. An investigation of risk factors for two successive cases of clinical mastitis in the same lactation. Livest. Sci. 194:10-16. https://doi .org/10.1016/j.livsci.2016.10.010.

Peeler, E. J., M. J. Green, J. L. Fitzpatrick, K. L. Morgan, and L. E. Green. 2000. Risk factors associated with clinical mastitis in low somatic cell count British dairy herds. J. Dairy Sci. 83:2464-2472. https://doi.org/10.3168/jds.S0022-0302(00)75138-1.

Sandrucci, A., L. Bava, M. Zucali, and A. Tamburini. 2014. Management factors and cow traits influencing milk somatic cell counts and teat hyperkeratosis during different seasons. Rev. Bras. Zootec. 43:505-511. https://doi.org/10.1590/S1516-35982014000900008.

Sargeant, J. M., A. O'Connor, I. R. Dohoo, H. N. Erb, M. Cevallos, M. Egger, A. K. Ersbøll, S. W. Martin, L. R. Nielsen, D. L. Pearl D. U. Pfeiffer, J. Sanchez, M. E. Torrence, H. Vigre, C. Waldner, and M. P. Ward. 2016. Methods and processes of developing the strengthening the reporting of observational studies in epidemiology - veterinary (STROBE-Vet) statement. Prev. Vet. Med. 134:188-196. https://doi.org/10.1016/j.prevetmed.2016.09.005. 
Shearn, M. F., and J. E. Hillerton. 1996. Hyperkeratosis of the teat duct orifice in the dairy cow. J. Dairy Res. 63:525-532. https://doi .org/10.1017/S0022029900032064.

Sieber, R. L., and R. J. Farnsworth. 1981. Prevalence of chronic teatend lesions and their relationship to intramammary infection in 22 herds of dairy cattle. J. Am. Vet. Med. Assoc. 178:1263-1267.

Sterrett, A. E., C. L. Wood, K. J. McQuerry, and J. M. Bewley. 2013. Changes in teat-end hyperkeratosis after installation of an individual quarter pulsation milking system. J. Dairy Sci. 96:4041-4046. https://doi.org/10.3168/jds.2012-6069.

Tancin, V., B. Ipema, P. Hogewerf, and J. Macuhova. 2006. Sources of variation in milk flow characteristics at udder and quarter levels. J. Dairy Sci. 89:978-988. https://doi.org/10.3168/jds.S0022 -0302(06)72163-4.

Wells, G., B. Shea, D. O'Connell, J. Peterson, V. Welch, M. Losos, and P. Tugwell. 2014. The Newcastle-Ottawa Scale (NOS) for assessing the quality of nonrandomised studies in meta-analyses. Accessed Dec. 10, 2018. http:// www.ohri.ca/programs/clinical_epidemiology/oxford.asp.
Zadoks, R. N., H. G. Allore, H. W. Barkema, O. C. Sampimon, G. J. Wellenberg, Y. T. Grohn, and Y. H. Schukken. 2001. Cow-and quarter-level risk factors for Streptococcus uberis and Staphylococcus aureus mastitis. J. Dairy Sci. 84:2649-2663. https://doi.org/10 .3168/jds.S0022-0302(01)74719-4.

Zoche-Golob, V., H. Haverkamp, J. H. Paduch, D. Klocke, C. Zinke, M. Hoedemaker, W. Heuwieser, and V. Krömker. 2015. Longitudinal study of the effects of teat condition on the risk of new intramammary infections in dairy cows. J. Dairy Sci. 98:910-917. https://doi.org/10.3168/jds.2014-8446.

Zucali, M., D. J. Reinemann, A. Tamburini, and R. D. Bade. 2008. Effects of liner compression on teat-end hyperkeratosis. Presented at the 2008 ASABE Annu. Int. Mtg., Rhode Island Convention Center, Providence, RI. Am. Soc. Agric. Biol. Eng., St. Joseph, MI.

\section{ORCIDS}

J. C. F. Pantoja () https://orcid.org/0000-0002-1648-9360 